УдК 061.75:(477-25).096:61:616.31

DOI 10.11603/2311-9624.2020.3.11575

\author{
(). А. Канюра, Н. В. Біденко, О. І. Коваль, П. В. Куц, А. О. Мельник,
}

\title{
В. В. Філоненко
}

Національний медичний університет імені О. О. Богомольця, м. Київ

e-mail: f.dental@nmu.ua

\section{0 років стоматологічному факультету Національного медичного університету імені О. О. Богомольця}

\section{ІНФОРМАЦІЯ}

Надійшла до редакції/Received: 01.09.2020 p.

Ключові слова: університет; факультет; стоматолог.

\section{АНОТАЦІЯ}

Резюме. У 2020 р. виповнюється 100 років від моменту заснування стоматологічного факультету Національного медичного університету імені О. О. Богомольця. Тому було видано наказ, згідно з яким одонтологічний інститут, створений у 1919 р. в Києві, приєднався до Інституту охорони здоров'я як окремий його факультет. Протягом свого існування факультет двічі (у 1931 і 1945 рр.) реорганізовувався в окремий стоматологічний інститут. У 1955 р. він остаточно трансформувався у стоматологічний факультет Київського медичного інституту імені академіка О. О. Богомольця. Сьогодні на факультеті працюють понад 150 викладачів на профільних кафедрах, 3 яких 16 докторів наук, 1 член-кореспондент НАМН України, 4 заслужені діячі науки і техніки України, 7 заслужених лікарів України, вчаться понад 1500 студентів-стоматологів з України та інших країн світу. 9 жовтня 2020 р. відбулися урочисті збори з нагоди 100-річчя стоматологічного факультету.
У 2020 р. виповнюється 100 років від моменту заснування стоматологічного факультету Національного медичного університету імені О. О. Богомольця. Хоча загалом вища освіта для стоматологів у Києві була започаткована раніше, ще у 1919 р., коли було створено перший в країні Одонтологічний інститут.

1 жовтня 1918 р. вийшов декрет Народного комісаріату охорони здоров’я про реформу зуболікарської освіти, в якому говорилося: «Отныне зубоврачебное образование будет неразрывно связано со всей системой высшего медицинского образования». Влітку 1919 р. Наркомохоронздоров'я видав декрет про передачу зуболікарської освіти медичним факультетам університетів і про закриття приватних зуболікарських шкіл, перетворивши їх на Державні Зуболікарські Клініки, що існували як навчально-допоміжні установи при медич- них факультетах університетів. Наркомом охоронздоров'я України було вирішено в негайному порядку відкрити замість зуболікарських шкіл Вищий науково-навчальний заклад - Державний Одонтологічний Інститут із чотирирічним курсом навчання. Очолив його Л. А. Білейкін. Проте через складнощі воєнного часу, тяжку економічну ситуацію, відсутність викладачів із теоретичних дисциплін і відповідного матеріального забезпечення новоствореному інституту на судилося повноцінно почати навчання. 18 жовтня 1920 р., після повернення радянської влади до Києва, міський Губвиконком видав наказ, згідно 3 яким Одонтологічний інститут було приєднано до Інституту охорони здоров'я (нині - Національний медичний університет імені О. О. Богомольця) як окремий його факультет. Так, у 1920 р. було створено перший одонтоло- 
гічний факультет в Україні, а його деканом було призначено К. П. Тарасова (рис. 1).

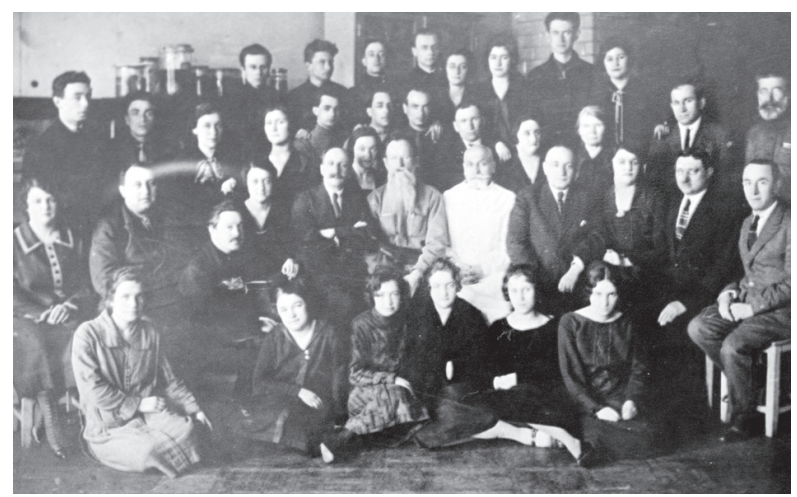

Puc. 1. Колектив одонтологічного факультету. В центрі - К. П. Тарасов (20-ті роки XX ст.).

Викладання на факультеті почалося призначеним організаційним складом викладачів за нашвидкуруч складеними програмами і планами. Для їх серйозної попередньої розробки не було часу, адже розпочинати викладання потрібно було негайно, за будь-яких умов. Відповідно до положення одонтологічний факультет як господарсько-адміністративна одиниця зливався 3 медфаком в одне ціле медакадемію, і матеріально-навчальні інтереси обох факультетів визначали як рівноцінні. У навчально-педагогічному аспекті факультет визначався як самостійний навчальний заклад; програми, система і методи викладання медакадемії формувалися залежно від спільної мети - підготовки кваліфікованих фахівців одонтології.

у 1930 р. одонтологічний факультет був перейменований у стоматологічний, а в 1931 р. він був реорганізований у самостійний Київський Стоматологічний інститут. Це значно підняло авторитет професії стоматолога серед молоді, інститут перестав відчувати нестачу абітурієнтів, йому були надані клінічні бази, а у 1931 р. при Київському інституті ортопедії і травматології була відкрита клініка щелепно-лицевої хірургї, спочатку на 16 ліжок, а 3 1937 р. - на 40 ліжок, яка діяла на цій базі до 1964 р. У довоєнний період деканами були С. Н. Вайсблат (1935-1938 рр.) й I. С. Гінзбург (1938-1940 рр.). Перед війною, з 1931 до 1940 р., Київський стоматологічний інститут підготував 1250 лікарів-стоматологів.

3 початком війни, у червні 1941 р., Київський стоматологічний інститут був евакуйований спочатку до м. Харкова, а потім - до м. Фрунзе, де він працював як факультет медичного інституту. Більшість співробітників кафедр надавала медичну допомогу в госпіталях та інших лікувальних закладах. Чимало викладачів та студентів і випускників опинились на фронті. Після визволення Києва у 1943 р. стоматологічний факультет був відновлений у складі медичного інституту.

У 1945 р. стоматологічний факультет вже вдруге був реорганізований у стоматологічний інститут. Поступово розширювалися його навчальні бази, формувалися наукові та педагогічні кадри. У 1947-1948 навчальному році в інституті навчалося близько 1000 студентів (рис. 2).

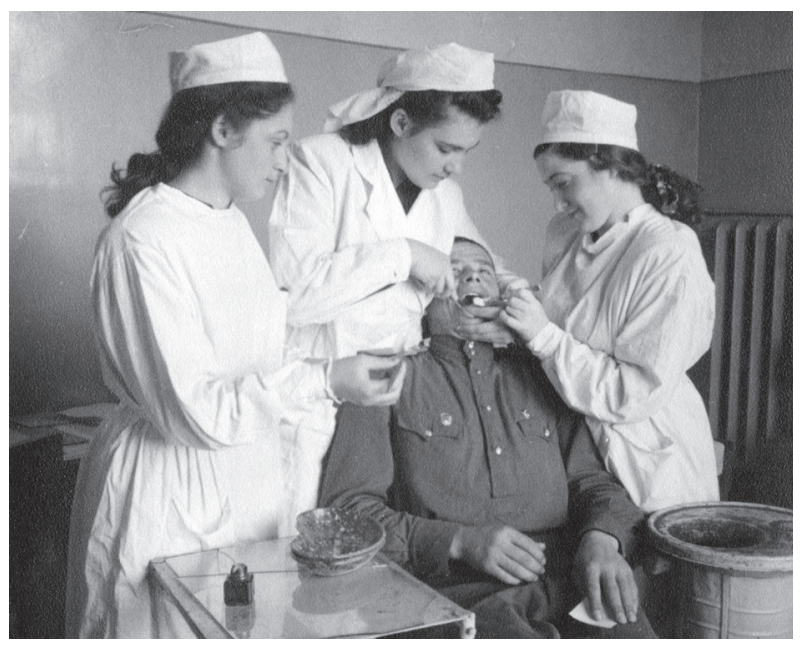

Puc. 2. Відпрацювання лікарських навичок. Прийом пацієнтів студентами Київського стоматологічного інституту (50-ті роки XX ст.).

Наказом №7 50 МО3 УРСР від 31.12.1954 р. 31 лютого 1955 р. Київський медичний стоматологічний інститут було ліквідовано і на його базі організовано стоматологічний факультет Київського медичного інституту імені академіка О. О. Богомольця. Реорганізація сприяла значному поліпшенню навчально-методичної роботи на профільних кафедрах, зріс рівень викладання теоретичних та загальномедичних дисциплін. Факультет очолювали такі видатні постаті, як О. П. Кисельова (1955-1960рр.), М. Ф. Данилевський (1960-1962 i 1966-1970 рр.), В. С. Коваленко (1962-1966 i 1971-1985 рр.), А. П. Грохольський (19851988 рр.), Д. В. Дудко (1988-1993 рр.). у 1964 р. була збудована основна клінічна база стоматологічного факультету НМУ - стоматологічний корпус, при будівництві якого враховувалась специфіка профільних кафедр (рис. 3-5).

Останні майже 30 років розвитку факультету були ознаменовані тим, що проходили в новий історичний період України. У цей час стоматологічний факультет, незважаючи на 


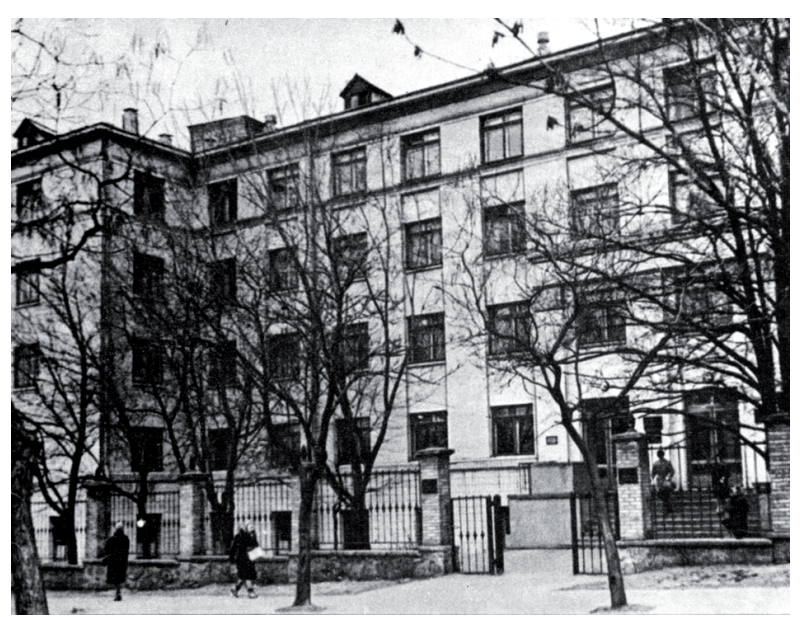

Puc. 3. Стоматологічний корпус (збудований y 1964 p.).

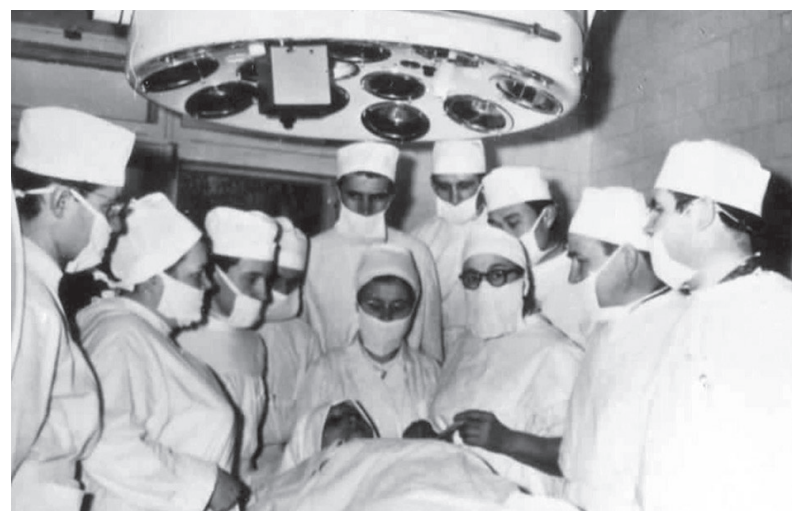

Puc. 4. Під час проведення операції (60-ті роки XX ст.).

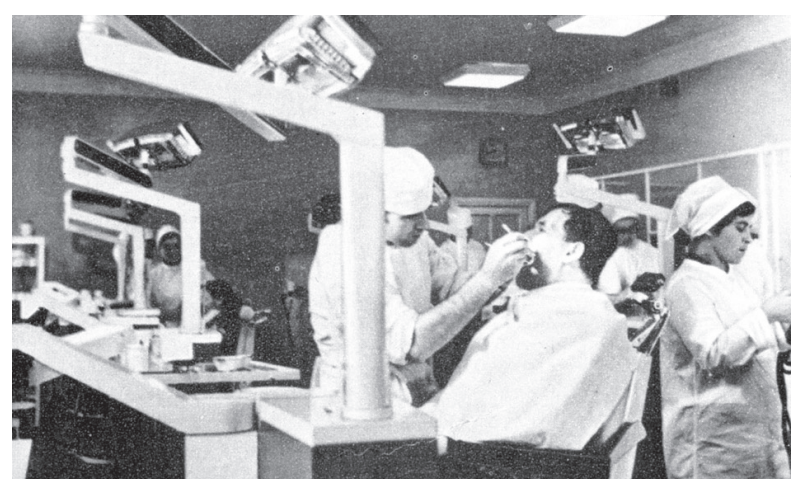

Puc. 5. Прийом пацієнтів студентами (70-ті роки XX ст.).

певні складнощі, отримав подальші можливості для успішного розвитку та удосконалення наукової і професійної майстерності колективу, особливо після надання університету статусу національного (рис. 6). Протягом 23 років факультет очолював видатний вчений і організатор, заслужений діяч науки і техніки України, В. П. Неспрядько; на сьогодні деканом факультету є професор Н. В. Біденко.

Вагомий внесок у розвиток професійної майстерності вносила Асоціація стоматологів

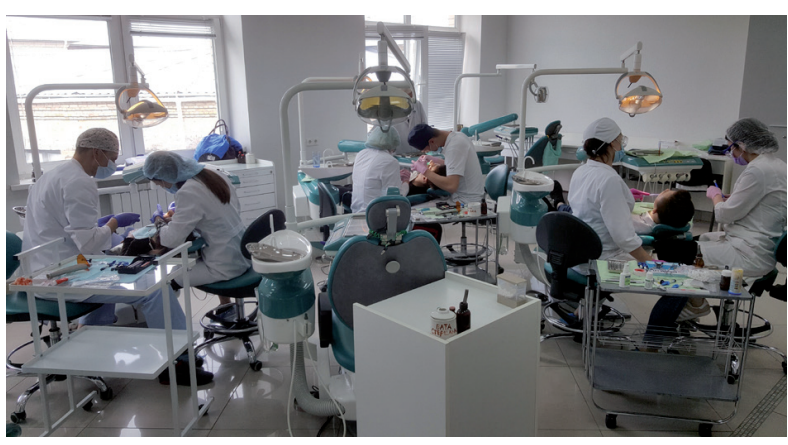

Puc. 6. Прийом пацієнтів студентами (2019 р.).

України, керівництво якою здійснювали професори стоматологічного факультету. Зокрема, професор М. Ф. Данилевський був першим президентом АСУ, професори В. П. Неспрядько, Л. О. Хоменко - віцепрезидентами, професор А. В. Борисенко - генеральним секретарем, професори В. О. Маланчук, Л. В. Харьков, П. С. Фліс - членами правління АСУ. 31998 р. Асоціація $€$ членом Всесвітньої організації стоматологів. На базі кафедр було створено профільні асоціації, а чимало співробітників факультету стали дійсними членами міжнародних асоціацій та професійних об’єднань.

Сьогодні стоматологічний факультет - це:

- понад 150 викладачів на профільних кафедрах, 3 яких 16 докторів наук, 1 членкореспондент Національної академії медичних наук України, 4 заслужені діячі науки і техніки України, 7 заслужених лікарів України, 24 члени міжнародних професійних організацій, понад 1500 студентів-стоматологів з України та більше ніж сорока інших країн світу, які навчаються на факультеті.

- потужна клінічна база - Стоматологічний медичний центр, який очолює професор А. В. Копчак і в якому надають стоматологічну допомогу тисячам жителів України; співробітники Центру та викладачі кафедр надають допомогу українським військовим, що відстоюють незалежність держави на Сході країни, беруть участь у волонтерських заходах та виїздах у зони проведення ООС.

- спеціалізована рада із захисту докторських та кандидатських дисертацій, яку очолює професор В. П. Неспрядько. Зростає рівень наукових досліджень, кафедри поповнюються талановитою молоддю, щороку захищають дисертаційні роботи як співробітники факультету, так і науковці з усіх закладів вищої медичної освіти України.

- численні міжнародні конференції: на базі кафедр, в аудиторіях Стоматологічного медичного центру часто виступають відомі зарубіж- 
ні фахівці, укладаються угоди про міжнародну співпрацю за різними напрямками фаху; водночас, співробітники факультету та медичного центру активно виступають і спілкуються 3 колегами за кордоном, а студенти та інтерни мають можливість стажуватись у медичних та освітніх закладах зарубіжжя.

- навчально-методична робота, що постійно удосконалюється, оновлюються навчальні плани, їх зміст гармонізується зі змістом європейських програм. Студенти мають можливість працювати на сучасному обладнанні, опановувати новітні методики діагностики та лікування в стоматології, проводять санітарно-просвітницьку роботу в дитячих закладах, на «наукових пікніках" для дітей. На факультеті одному з перших в Україні було запроваджено об’єктивний структурований клінічний іспит для студентів III i V курсів, введено книжки обліку практичних навичок із пропедевтики та з клінічної стоматології.

- студентська наука, що активно розвивається: вихованці стоматологічного факультету виступають на студентських наукових конференціях в університеті та за його межами, перемагають на всеукраїнських олімпіадах 3 різних дисциплін. Науковій та практичній підготовці студентів сприяє робота студентських наукових гуртків, що працю- ють на усіх кафедрах, організація численних майстер-класів. Для удосконалення володіння студентами англійською мовою професійного спрямування за участі кафедри іноземних мов (завідувач - доцент Л. Я. Аврахова) створено English speaking club for dentists, участь в якому беруть як молодші студенти, так і старшокурсники, аспіранти, молоді викладачі. Студенти долучаються до участі в наукових пікніках, де навчають дітей та їх батьків правильному догляду за зубами шляхам збереження стоматологічного здоров'я.

- студентські змагання - протягом останнix 20 років на стоматологічному факультеті щорічно проводяться міжнародні студентські змагання «Брейн-ринг зі стоматології». В них беруть участь команди з різних куточків України та ближнього зарубіжжя.

- дні факультету, що вже стали доброю традицією, і на яких яскраво виявляється студентська креативність.

На факультеті працює 6 профільних кафедр, на кожній з яких сформувались потужні наукові школи, знані як в Україні, так і за їі межами. Кафедру терапевтичної стоматології очолює професор А. В. Борисенко (рис. 7). У різні роки на кафедрі працювали І. Й. Новик, М. Ф. Данилевський, О. І. Марченко, Л. О. Хоменко, А. П. Грохольський, А. М. Політун.

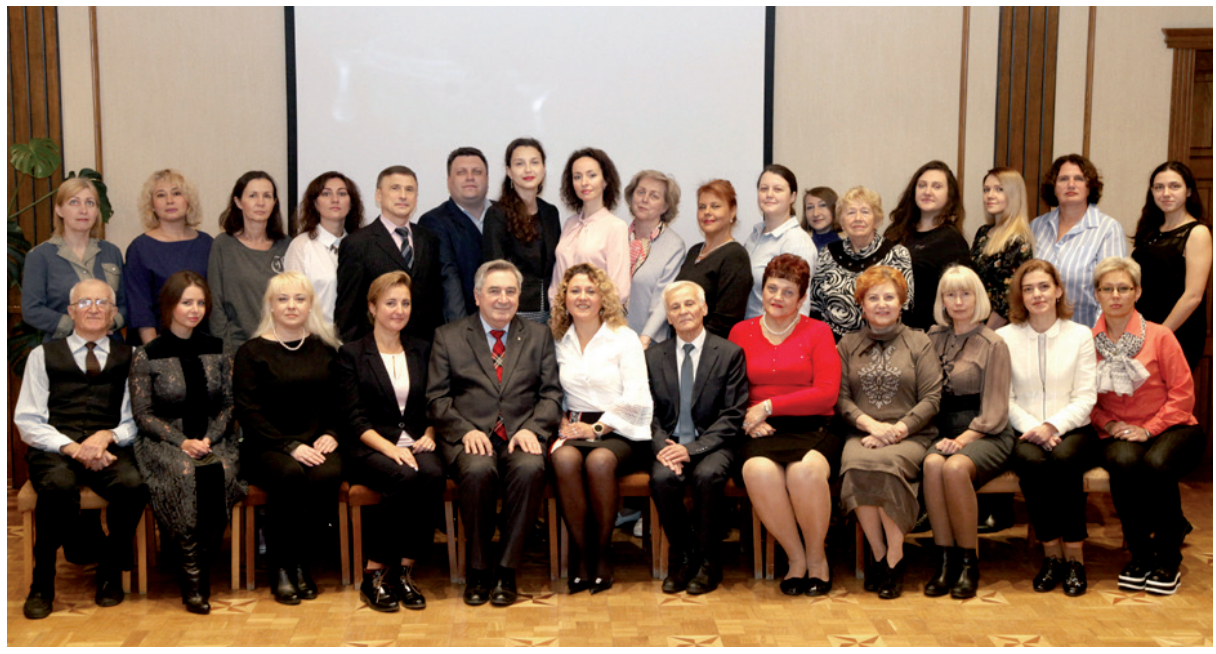

Puc. 7. Кафедра терапевтичної стоматології.

Кафедру хірургічної стоматології та щелепно-лицевої хірургії очолює член-кореспондент НАМН України, лауреат Державної премії України, заслужений діяч науки і техніки України професор В. О. Маланчук (рис. 8). Імена М. Й. Шапіро, С. Н. Вайсблата, Г. І. Семенченка, М. В. Фетисова, Ю. Й. Бернадського, Д. В. Дудко, що у різні часи керували кафедрою, відомі медичній спільноті не тільки України.

Кафедру ортопедичної стоматології очолює заслужений діяч науки і техніки України професор В. П. Неспрядько (рис. 9). Неосяжний внесок у розвиток кафедри і вітчизняної ортопедичної стоматології зробили видатні вчені Л. Н. Дудкін, А. І. Бетельман, С. Й. Криштаб, 3. С. Василенко. 
Ювілеї

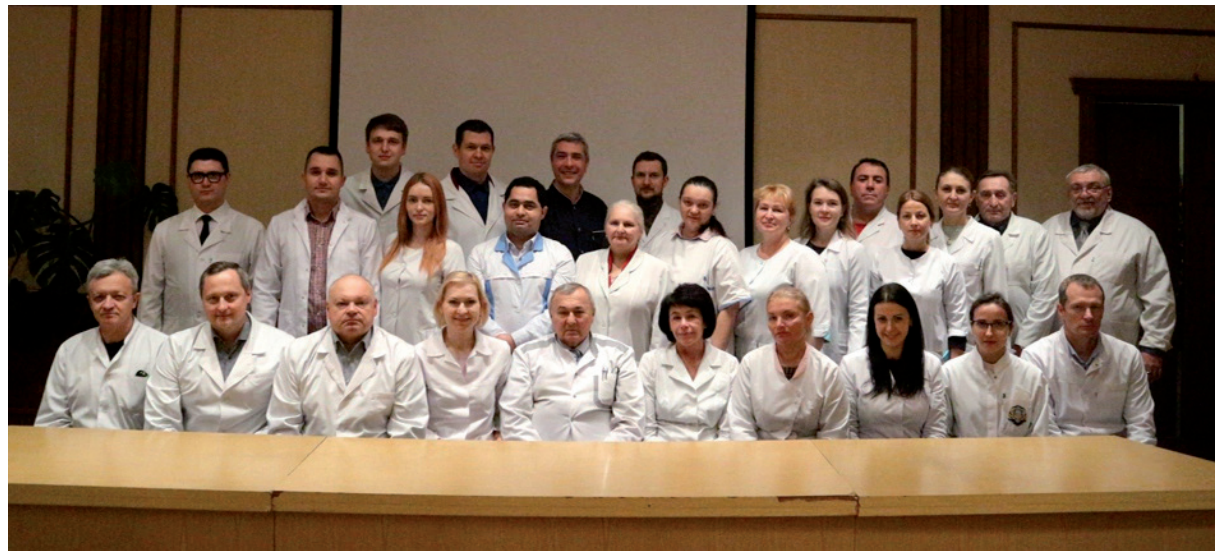

Puc. 8. Кафедра хірургічної стоматології та щелепно-лицевої хірургії.

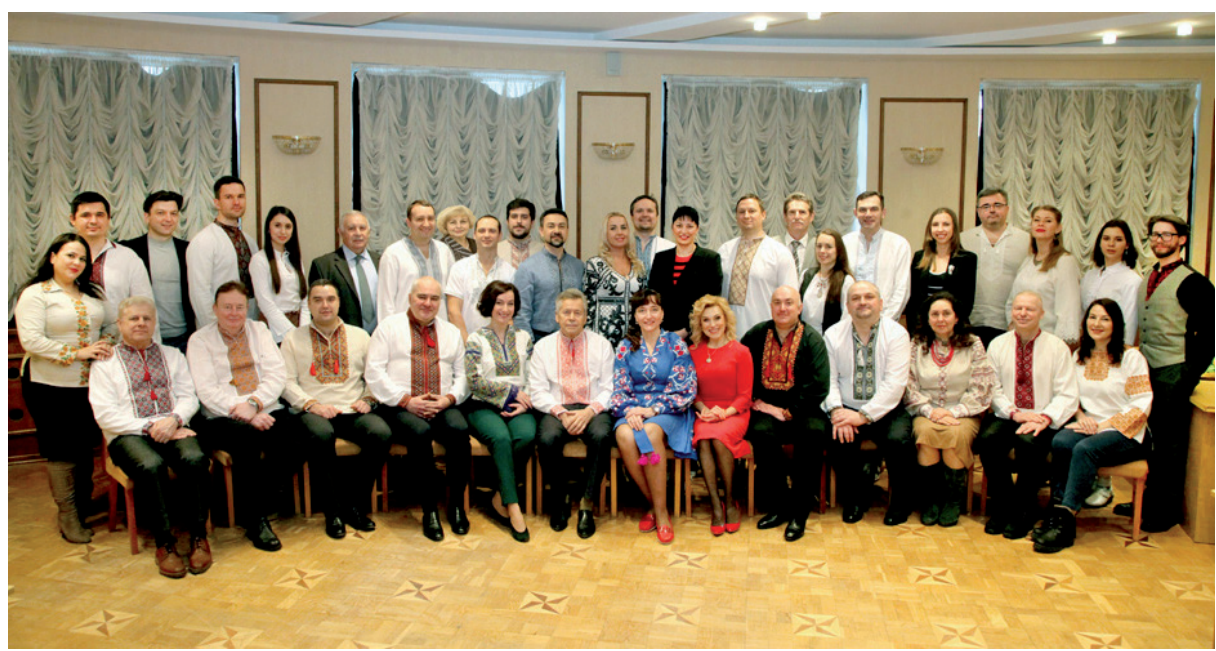

Puc. 9. Кафедра ортопедичної стоматології.

Кафедру дитячої терапевтичної стоматології та профілактики стоматологічних захворювань було створено у 1989 р. Понад 25 років їі очолювала заслужений діяч науки і техніки України професор Л. О. Хоменко, а зараз очолює професор О. В. Савичук (рис. 10).
Кафедру ортодонтії та пропедевтики ортопедичної стоматології очолює заслужений діяч науки і техніки України професор П. С. Фліс (рис. 11). До здобутків кафедри долучились відомі професори 3. С. Василенко, С. І. Дорошенко.

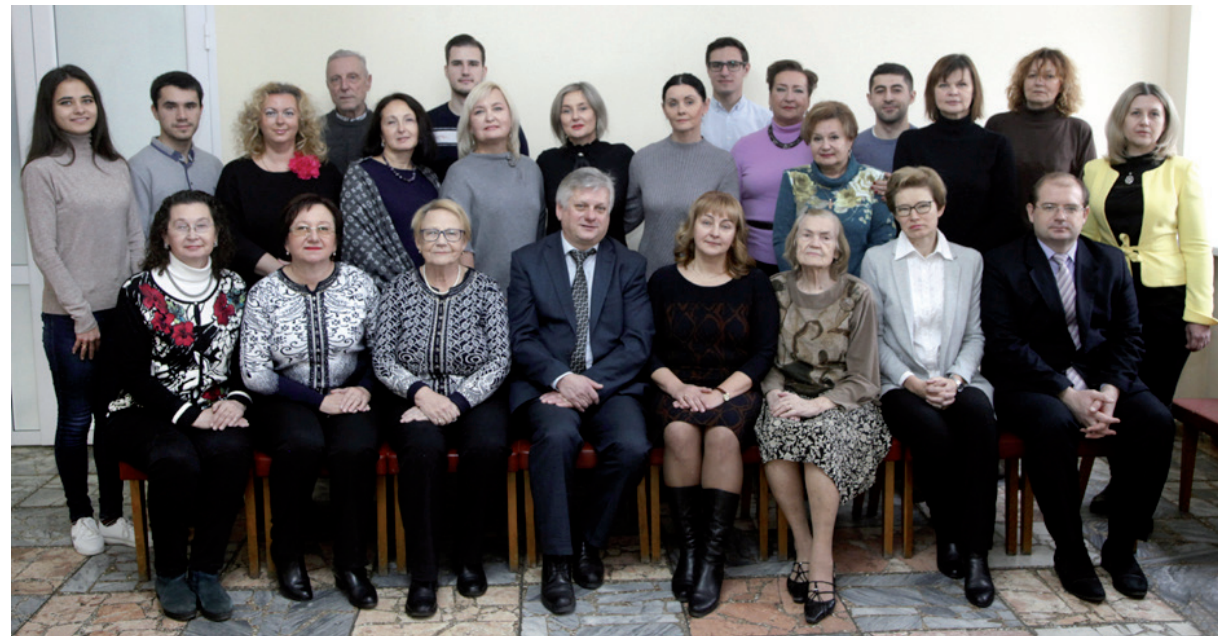

Puc. 10. Кафедра дитячої терапевтичної стоматології та профілактики стоматологічних захворювань. 
Ювілеї

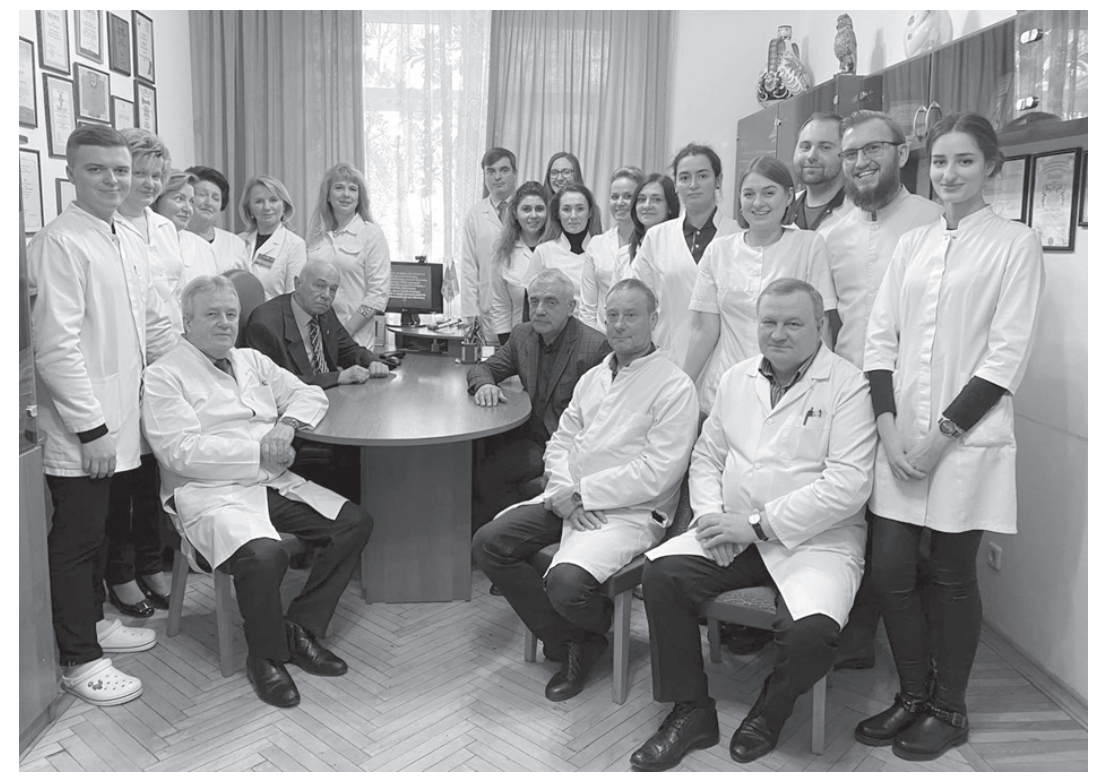

Puc. 11. Кафедра ортодонтії та пропедевтики ортопедичної стоматології.

Кафедру хірургічної стоматології та щелепно-лицевої хірургії дитячого віку очолює професор Л. М. Яковенка, а до того тривалий час очолював член-кореспондент НАМН України професор Л. В. Харьков (рис. 12).

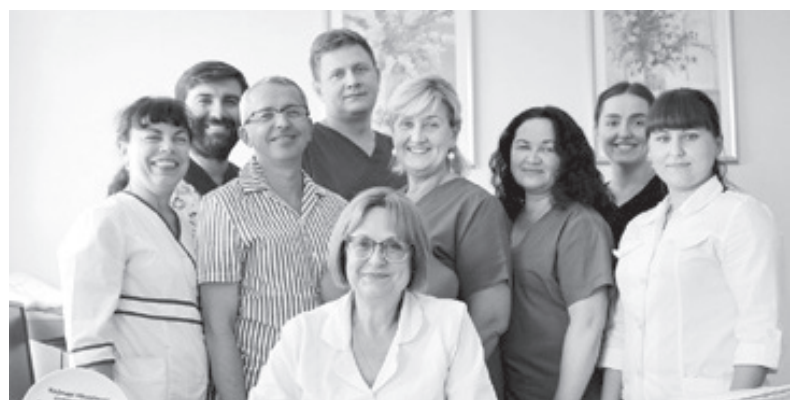

Puc. 12. Кафедра хірургічної стоматології та щелепно-лицевої хірургії дитячого віку.

9 жовтня 2020 р. відбулися урочисті збори 3 нагоди 100-річчя стоматологічного факультету (рис. 13).

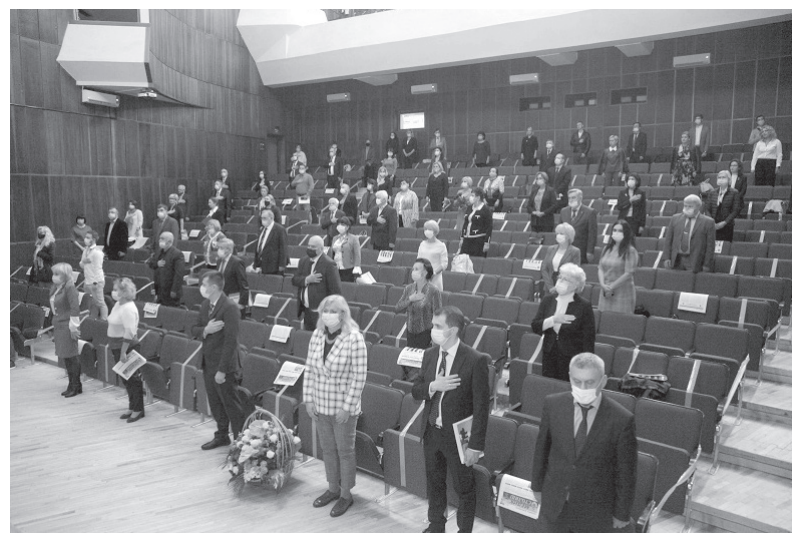

Puc. 13. Урочисті збори з нагоди 100-річчя стоматологічного факультету.
3 теплим привітанням на адресу факультету виступила перший заступник міністра охорони здоров'я України І. Д. Садов'як, яка від імені Міністра М. В. Степанова і всього апарату відомства відзначила роль і значення Університету і стоматологічного факультету як одного з його флагманів - зокрема, у розвитку медичної науки і освіти в Україні (рис. 14). Привітали стоматологів голова ради Київської профспілки працівників охорони здоров’я України С. А. Кубанський, Прези-

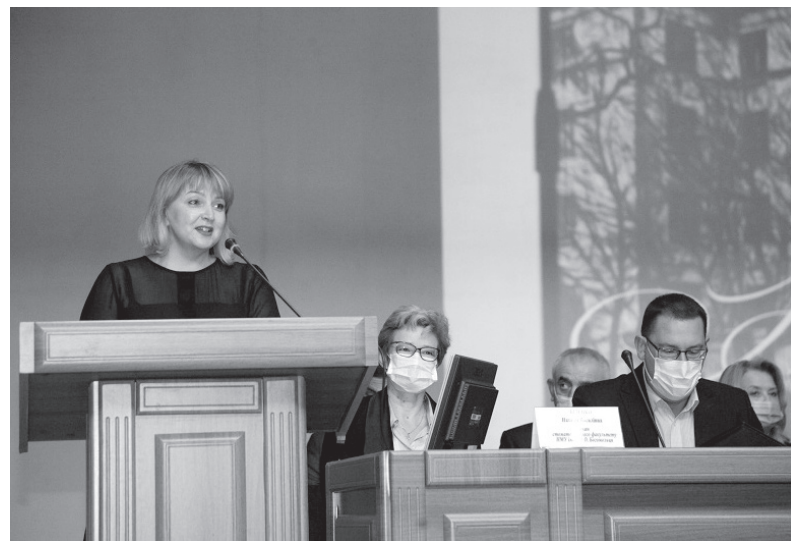

Puc. 14. Виступає перший заступник міністра охорони здоров’я України I. Д. Садов’як.

дент Асоціації стоматологів України професор І. П. Мазур. Ректор НМУ імені О. О. Богомольця професор Ю. Л. Кучин у вітальному слові відзначив роль стоматологічного факультету в Університеті як одну з провідних, зупинившись на основних віхах непростого шляху, який він подолав за 100 років. Адміністрація НМУ й особисто ректор Ю. Л. Кучин завжди

ISSN 2311-9624. Клінічна стоматологія. 2020. № 3 
підтримували факультет і на сьогодні приділяють значну увагу його розвитку (рис. 15).

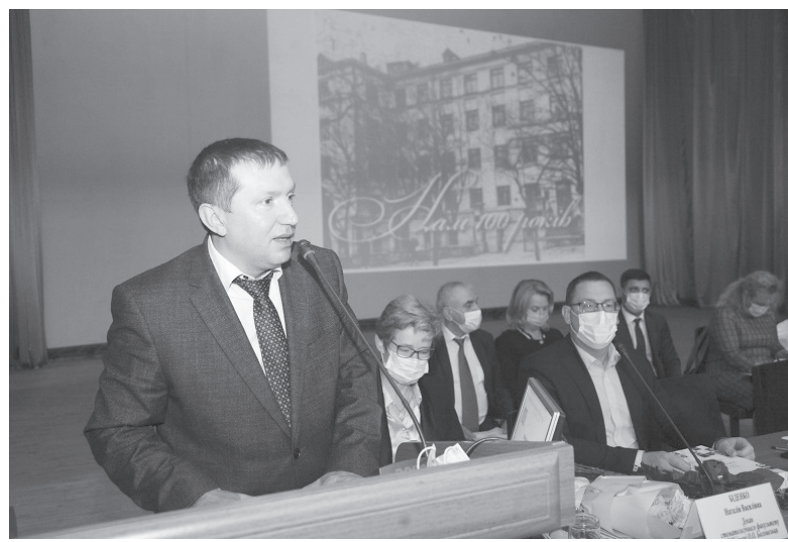

Puc. 15. Виступає ректор НМУ імені О. О. Богомольця професор Ю. Л. Кучин.

Виступи завідувачів профільних кафедр чергувалися 3 онлайн-привітаннями колег із медичних навчальних і наукових закладів України. Ювілярів привітали також колеги 3 Національної медичної академії післядипломної освіти імені П. Л. Шупика та Київського медичного університету.

Із програмною доповіддю «Шлях довжиною у 100 років» виступила декан стоматологічного факультету професор Н. В. Біденко (рис. 16). Основні етапи становлення, розвитку факультету і його сьогодення представлені у виданій до ювілею книзі авторського колективу в складі Н. В. Біденко, А. В. Борисенка, О. А. Канюри, Ю. В. Клітинського, П. В. Куца, I. П. Мазур, В. О. Маланчука, В. П. Неспрядька,

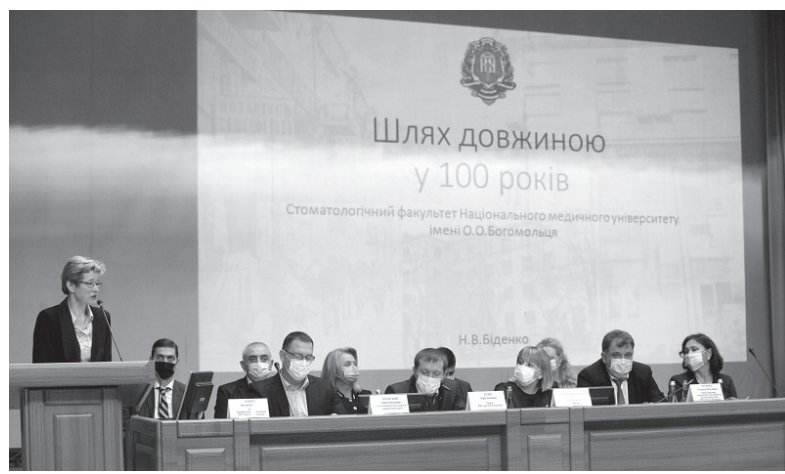

Puc. 16. Доповідь «Шлях довжиною у 100 років» декана стоматологічного факультету професора Н. В. Біденко.
К. Є. Печковського, О. В. Савичука, І. Л. Скрипник, В. В. Філоненка, П. С. Фліса, Л. О. Хоменко, г. І. Шаповалової, Л. М. Яковенко «Шлях довжиною у сто років (1920-2020 pp.): Стоматологічний факультет Національного медичного університету імені О. О. Богомольця» [1]. Текст і фото даної книги стали основою даної публікації. Історія факультету також представлена в урочисто відкритій цього ж дня музейній експозиції у Стоматологічному медичному центрі (рис. 17) [2].

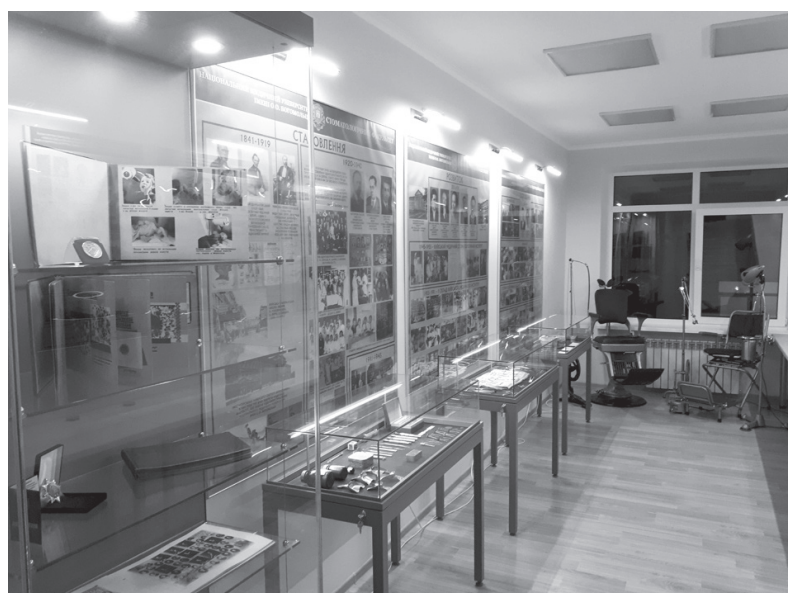

Puc. 17. Музейна експозиція у Стоматологічному медичному центрі.

Знання і вшанування своєї історії - це запорука розуміння подій, що відбуваються з нами сьогодні, вміння передбачати, що буде з нами завтра. За словами давньогрецького вченого, засновника історичної науки Фукідіда, «історія - це філософія на прикладах». Ми крокуємо лабіринтами спогадів, документів, подій, вдивляючись в обличчя тих, хто протягом усіх цих років творив історію першого в Україні стоматологічного факультету, дослухаючись до їх слів, часто пророчих, дивуючись їх енергії, наполегливості, самовідданості на шляху до розбудови медичної освіти. Вклоняємось тим, хто мав мужність бути першими, видатним Ученим, нашим Учителям і Наставникам, бо, перефразовуючи вислів Ісаака Ньютона, легко бачити далі, стоячи на плечах велетнів. Минулим - пишаємось, сьогодення - цінуємо, майбутнє - створюємо. 


\title{
(ㄱ. А. Канюра, Н. В. Биденко, О. И. Коваль, П. В. Куц, А. А. Мельник, В. В. Филоненко
}

Национальный медицинский университет имени А. А. Богомольца, г. Киев

\section{0 лет стоматологическому факультету Национального медицинского университета имени А. А. Богомольца}

Резюме. В 2020 г. исполняется 100 лет с момента основания стоматологического факультета Национального медицинского университета имени А. А. Богомольца. Поэтому был издан приказ, согласно которому одонтологический институт, созданный в 1919 г. в Киеве, присоединился к Институту здравоохранения как отдельный его факультет. На протяжении своего существования факультет дважды (в 1931 и 1945 гг.) реорганизовывался в отдельный стоматологический институт. В 1955 г. он окончательно трансформировался в стоматологический факультет Киевского медицинского института имени академика А. А. Богомольца. Сегодня на факультете работают более 150 преподавателей на профильных кафедрах, из которых 16 докторов наук, 1 член-корреспондент НАМН Украины, 4 заслуженных деятеля науки и техники Украины, 7 заслуженных врачей Украины, учатся более 1500 студентов-стоматологов из Украины и других стран мира. 9 октября 2020 состоялось торжественное собрание по случаю 100-летия стоматологического факультета.

Ключевые слова: университет; факультет; стоматолог.

\author{
O. A. Kaniura, N. V. Bidenko, O. I. Koval, P. V. Kuts, A. O. Melnyk, V. V. Filonenko \\ O. Bohomolets National Medical University, Kyiv
}

\section{0th birthday of the Dental faculty of 0 . Bohomolets National Medical University}

Summary. The year 2020 marks the 100th anniversary of the Dental faculty of O. Bohomolets National Medical University. In 1920, an order was issued, according to which the odontological institute, created in 1919 in Kyiv, was joined to the Institute of Public Health as its separate faculty. Throughout its existence, the faculty was reorganized twice (in 1931 and 1945) into a separate dental institute. In 1955, it was finally transformed into the dental faculty of the Kyiv Medical Institute named after academician O. Bohomolets. Today, the faculty employs more than 150 teachers in specialized departments, of which 16 are Doctors of Sciences, 1 Corresponding Member of the National Academy of Medical Sciences of Ukraine, 4 Honored workers of science and technology of Ukraine, 7 Honored doctors of Ukraine, more than 1.500 dental students from Ukraine and other countries all over the world study here. On October 9, 2020, a solemn meeting was held to mark the 100th Anniversary of the Dental Faculty.

Key words: university; faculty; dentist.

\section{СПИСОК ЛІТЕРАТУРИ}

1. Шлях довжиною у сто років (1920-2020): Стоматологічний факультет Національного медичного університету імені О. О.Б огомольця / уклад. Н. Біденко, Ю. Клітинський. - Дніпро : Середняк Т. К., 2020. -332 c.

\section{REFERENCES}

1. Bidenko, N., \& Klitynskyi, Yu. (Comp.). (2020). Shliakh dovzhynoiu u sto rokiv (1920-2020): Stomatolohichnyi fakultet Natsionalnoho medychnoho universytetu imeni O.O. Bohomoltsia [One hundred years long path (19202020): Faculty of Dentistry of the National Medical
2. http://nmuofficial.com/news/urochysti-zbory-z nagody-100-richchya-stomatologichnogo-fakultetunmu-imeni-o-o-bogomoltsya/

University named after O.O. Bohomolets]. Dnipro: Seredniak T.K. [in Ukrainian].

2. http://nmuofficial.com/news/urochysti-zbory-znagody-100-richchya-stomatologichnogo-fakultetunmu-imeni-o-o-bogomoltsya/ 